Mammal House in the Middle Gardens began. In October the Snowdon Aviary was opened to visitors. Among the births in the Collection in 1965 were two red deer and four blackbuck; on the Mappin Terraces wild boars were born and the seven piglets trotting around the enclosure with their mother have been a great attraction. In the Monkey House a tufted capuchin monkey, the first since 1935, and a mandrill were born; and in the Chimpanzee Breeding House, established in May 1964, two female chimpanzees were born but, unfortunately, one has since died. While chimpanzees are perhaps one of the most common of zoo animals, comparatively few are bred in captivity. In recent months, a lion, a puma, a Chinese leopard, two Caracal lynxes, Arctic foxes, a Syrian bear, an American bison and a walleroo have been born. Among the birds hatched were four Kenya eagle owls, two spotted eagle owls and a barn owl. One of the most exciting additions to the bird collection was a magnificent group of 24 birds of paradise presented by Sir Edward Hallström to mark the visit of Earl Mountbatten of Burma, accompanied by Sir Solly Zuckerman, to Taronga Zoological Park, Sydney. These birds are rarely seen outside Australasia. This superb collection includes the ribbon tail, the sickle bill and lesser superb birds of paradise, the magnificent bird of paradise and the raggi bird of paradise. As part of the same collection, Sir Edward Hallström presented six green pythons, which are some 3-5 ft. long. Lord Chaplin, a former secretary of the Society, brought back from Trinidad an interesting collection of reptiles and amphibians, including four species of frogs new to the London Zoo-the spotted tree frog, the Trinidad golden tree frog, Fitzgerald's marsupia] frog and the giant tree frog. The number of visitors to the Gardens in 1965 was considerably higher than in 1964.

\section{Vegetation of Uganda}

I. Langdale-Brown, J. A. Osmaston and J. G. Wilson have produced a detailed and authoritative account of the vegetation of Uganda (The Vegetation of Uganda and Its Bearing on Land-Use. Pp. $159+24$ plates. Entebbe: Government Printer; London: The Uganda High Commission, 1964. 30s.). This will be invaluable for all students of the ecology of the country and for all those engaged in the improvement of land use both for agriculture and livestock production and for forestry. The book is well produced by the Government of Uganda, well illustrated and supported by a substantial folder of maps. It is to be recommended to all those concerned with development in Uganda and to botanists interested in the vegetation of the Equatorial Great Iakes Region.

\section{American Geographical Society: Awards}

THe following awards of the American Geographical Society have been presented: David Livingstone Cen. tenary Medal, to Dr. Bassett Maguire, for his scientific achievement in the geography of the Southern hernisphere; Cullum Geographical Medal, to Prof. K. F. Mather, for distinguished service in the advancement of geographical science; Charles P. Daly Medal, to Prof. W. S. Cooper, for distinguished geographical services as a plant ecologist and geomorphologist; Honorary Fellowships, to Prof. M. J. Dumbar, for his outstanding contributions to geography through the disciplines of marine science, and to Dr. P. Meigs, in recognition of his work in the problems of water resources, arid lands, climatology and historical geography.

\section{University News:}

Belfast

H. R. MARTIN has been appointed to a lectureship in mechanical engineering.

Bristol

THe following lecturers have been appointed: Dr. E. G. Fllison (mechanical engineering); Dr. J. Hindley (bio- chemistry); Dr. M. S. Knapp (medicine); Dr. F. P. Sayer (theoretical mechanies). The title of professor emeritus has been conferred on the following: Prof. W. Baker (formerly professor of organic chemistry); Prof. R. J. Brocklehurst (formerly professor of physiology).

Leeds

Prof. P. Gray has been appointed professor of physical chemistry and head of the Department of Physical Chemistry. Dr. F. G. Holliman has been appointed to an additional chair of organic chemistry. Dr. D. R. Baulch has been appointed lecturer in the Department of Physical Chemistry. The title of reader has been conferred on the following: Dr. K. S. Zinnemann (bacterio$\operatorname{logy}$ ); Dr. B. E. C. Nordin (in respect of his post as director of the Minoral Metabolism Research Unit of the Medical Research Council).

London

THE following readers have been appointed: Dr. D. C. Watts (biochemistry), tenable at Guy's Hospital Medical School; Dr. D. W. Allan (mathematics), tenable at King's College. The following title has also been conferred: H. Billett, professor of mechanical engineering, in respect of his post at University College.

\section{Manchester}

THE title of professor emeritus has been conferred on the following: Prof. E. W. Anderson (formerly professor of psychiatry and director of the Department); Sir Robert Platt (formerly professor of medicine); Prof. W. Schlapp (formerly Brackenbury professor of physiology and director of the physiological laboratories).

\section{Announcements}

Prof. Marcel Nicolet, Dr. Sydney Chapman and Dr. Joseph Kaplan have been awarded the Hodgkins Gold Medal of the American Meteorological Society, for their outstanding contributions to the field of atmospheric research.

THE fourth Matscience Anniversary Symposium will be held at the Institute of Mathematical Sciences, Madras, during January 3-14. Further information can be obtained from the Institute of Mathematical Sciences, Central Polytechnical Buildings, Adyar, Madras 20.

A MEeting of the Biochemical Society will be held in the University of Sheffield during January "5-6. The programme will include a colloquium on "Control of Enzyme Patterns in Tissues". Further information can be obtained from the Administrative Secretary, the Biochemical Society, 20 Park Crescent, London, W.1.

A symposium on "Cutting Costs through the Control of Quality", arranged by the Institution of Engineering Inspection, will be held in the University of Strathelyde on January 6 . Further information can be obtained from the Secretary, Institution of Engineering Inspection, 616 Grand Buildings, Trafalgar Square, London, W.C.2.

AN evening meeting of Aslib will be held in London on January 27. The programmo will include a lecture by H. A. Chesshyre (Hatfield College of Technology) on "Local Co-operation: a Positive Force". Further information can be obtained from the Meotings Organizer, Aslib, 3 Belgrave Square, London, S.W.1.

THE Royal Institution Christmas Lectures for Young People will be delivered by Sir Bernard Lovell, Prof. F. Graham Smith, Prof. Martin Ryle and Dr. A. Hewish on "The Exploration of the Universe". The lectures will include: introduction and techniques (December 28); the solar system (December 30); the Earth as a planet (January 1); the Milky Way (January 4); radio galaxies (January 6); cosmology (January 8). Further information can be obtained from the Royal Institution, 21 Albemarle Street, London, W.1. 